\title{
Judicial Activism in the World Trade Organization: A Conundrum and Selective Approach
}

\author{
Kiyoung Kim* \\ Department of Law and Public Service, College of Law, Chosun University, Gwangju, South Korea \\ Email: kiyoungkim@chosun.ac.kr
}

How to cite this paper: Kim, K. (2020). Judicial Activism in the World Trade Organization: A Conundrum and Selective Approach. Beijing Law Review, 11, 827-855. https://doi.org/10.4236/blr.2020.114050

Received: August 5, 2020

Accepted: December 1, 2020

Published: December 4, 2020

Copyright $\odot 2020$ by author(s) and Scientific Research Publishing Inc. This work is licensed under the Creative Commons Attribution International License (CC BY 4.0).

http://creativecommons.org/licenses/by/4.0/

\begin{abstract}
With the establishment of the World Trade Organization in 1995, the dispute settlement mechanism for international trade was greatly prepared unlike the old GATT system. It has a very different pattern from that of original GATT system. In our case, international trade is a matter of the future of nations, and in reality of the intense world economic competition, this system change may well be of concern to our government or legal experts. In this context, this paper examines the nature and problems of the WTO appeal system under the premise of the rule of law, judicial prowess, and the role of a judge. The WTO dispute settlement mechanism is based on the domestic judicial system or other international judicial systems. In contrast to this, the comparative history is only short indeed, but according to the accumulation of future precedents, it is highly possible to provide a model for the achievement of the rule of law ideals in the international community. However, due to the inherent limitations of international agreement system, the reality of appellate body is not easy. In terms of the international trade and rule of law, the role of appellate body and judges is very broad. However, in this paper, we first look at the significance and nature of the launch of WTO and furthermore; 1) the rule of law and judicial system, 2) several issues related to the nature of WTO dispute settlement mechanism, 3) the importance of judge-made law and the scope and limitations of appellate jurisdiction, 4) issues
\end{abstract}

*Professor of Law and Public Policy, Chosun University; Bar Membership, New York State, US Court of Appeals Ninth Circuit, Republic of Korea; Dr. Iuris, Seoul National University/Korean Judicial Research Institute, 1987; LL.M., East Asian Legal Studies Center, University of Wisconsin-Madison, 1994; SJD, East Asian Legal Studies Center, University of Wisconsin-Madison, 1995; PH.D (International Relations and Diplomacy), Centre des Etudes Diplomatiques et Strategiques (INSEEC), Academie de Paris, 2003; D.PHIL (Public Policy), Walden University (Flagship, Laureate International), 2018; Ph.D. (Business Administration), Chosun University, 2020. I want to thank the faculty of Chosun Law for helpful comments to refine this Essay. Any errors must be mine. 
of reference materials submitted by procedures outside the process, 5) the relationship between the appellate body and political authorities. Over the review, the penetrating thoughts will be focused on judicial activism. Those points of consideration will be discussed through the approach and method on the comparative legal studies and several significant WTO precedents.

\section{Keywords}

WTO, Appellate Body, Judicial Activism, Rule of Law, Judge-Made Law, Dispute Settlement Mechanism

\section{Introduction}

Unlike the old GATT system, the dispute settlement procedure of World Trade Organization (hereinafter referred to as WTO) was extensively revised in 1995 with the launch of new framework. It is very different from the old system, to illustrate, the adoption of reverse consensus system, specification of time limit on procedure, and establishment of appellate body (hereinafter referred to as $A B$ ), which aims to envision the rule of law in international trade regime. For the state actors, international trade often would be a problem of the keen national interest. In fact, the world gradually is becoming to be competitive surrounding the trade interest, in which the paradigm change is a concern of government or legal experts. In this context, this paper illuminates and examines the nature or problems of WTO framework under the thesis of rule of law, judicial activism, and role of judge. Unlike the domestic judiciary or other international judicial systems, the WTO dispute settlement mechanism has a relatively short history. Nevertheless, with the rapid evolution with accumulation of precedents, it is likely to provide a model for achieving the rule of law in the international community. However, due to inherent limitations of the international treaty system, challenges faced by the panel or appellate body are never nugatory. In this paper, we first examine the significance or nature within the establishment of WTO, and then examine the judicial face of WTO dispute settlement mechanism. Over chapters, we will discuss related topics concerned with the nature of judge-made law, scope and limitations of appellate jurisdiction, issues of reference materials submitted by the actors outside the procedure, relationship between the appellate body and political organs, as well as judicial activism.

\section{Background}

The history of mankind can be viewed from various perspectives even if we are ignorant of propositions or theories from historians. It may be a history of war and conquest as well as a society that is improved by the power of human intelligence and freedom. It also may be a historical necessity that develops according to the conflict between the relations of economic production and labor or productivity. If you are asked to exemplify any greatest stroke in the human history, 
many will be indulged to illustrate the first and second world wars. As the war ended with the victory of allies, major world powers responded to the demand of international community for peace, thus creating the United Nations as a political entity and the system on the General Agreement on Tariffs and Trade (hereinafter referred to as GATT) for international trade. It is a well-known fact that the GATT system was launched in 1947 instead of the International Trade Organization (ITO), which was originally conceived by the powers as a principal management authority for the real sector of world economy in parallel with the IMF (International Monetary Fund) and IBRD (International Bank for Reconstruction and Development). From this point of view, human history is neither necessarily a history of war and conquest nor is a historically inevitable process in accordance with the contradictions of production relations and labor forces as prophecies of genius economist. I think that the history is not so wrong if it is being improved through a positive function of human reason and freedom even under the ideology or dogmatic form of theory. 1947 GATT system has functioned as a management system concerning the international trade for a long time, and in 1986, the GATT became transferred to a new frame of WTO-extended and deepened creature to manage the world trade-as a result of seven years multilateral negotiation, so-called Uruguay Round (Dam, 1970; Carr \& Stone, 2017; Bethlehem, McRae, Neufeld, \& Van Damme, 2009; Seo, 2001; Lee, 1999a).

The WTO does not presuppose a complicated logical analysis. However, it is in same sense as a resurgence of the International Trade Organization at the trade station, which had once been the ideal of mankind in the past. If we understand the important characteristics of global community in view of political economic phenomenon, we can see that humanity is integrated politically and economically through such ideal organization of United Nations and World Trade Organization. There can we suggest the critical viewpoints to this ideal system from several perspectives. First, some scholars reduce the meaning of United Nations and World Trade Organization in terms of international political realism. Second, others may hold a view to pay attention to the phenomenon of localization or globalization of the world in opposition to a unification theory of international society. In other words, such camp of thought criticizes the idealism for global economic integration based on the critical importance of region for economic cooperation or integration, or the glocalization hypothesis for political and cultural specificity. Third, there is a reformist position to achieve idealistic integration by collecting the wisdom of mankind while improving the current system of United Nations and WTO. These views are not pure idealism in that they accept the political and economic reality of international community.

What do the United Nations and World Trade Organization, representing the ideals of mankind, cast implications in terms of human integration? What about the future of such an organization in the political and economic reality with a sharp confrontation of interests among nations? In this article, I would like to discuss the international trade law of WTO in terms of meaning and integration 
attached with the global economy (Auby, 2003). At the beginning of political economics, what we learn is that the reality of economy is not to work in accordance with pure market principles. A liberal regime and market principle are theories and principles that support the development of modern civil society and democracy, but the failure of domestic and global market pertaining the international trade are the reality that we all must accept (Lee, 1999b). The failure of market inevitably leads to regulation, domestic regulation of the economy, international regulation, and regime of trade management (1999). In 1947, the GATT system was lacking in many ways. To complement this, the WTO system was launched at the end of negotiation over a long period of seven years. In ideal, no one will hesitate to take it as the kind of "democratization of the economy" and "establishment of the rule of law in international trade", which triggers the transformation of systems into a multilateralist system. In other words, the new start with WTO is revolutionary in that it is a system to overcome an alienation phenomenon, say, anti-discrimination within the international trade system, including the unreasonable economic pressure and gray-area measures that persisted in the past.

One of great features in the WTO system is the efficiency and strengthening of dispute settlement procedure (Lee, 1999a). This can be said that the WTO system generally would be any most successful paradigm having realized the rule of law within the arena of international trade. The history of mankind demonstrates that the trajectory to integrate subjects into a system politically and economically begins from the stage of political inclusion through economic integration (Auby, 2003).

Of course, the order may differ or comes inverse. In the case of United States (hereinafter referred to as US), integration was achieved through political independence waging a bitter war and by the enactment of federal constitution. One of the most important provisions concerning incorporation of sovereign states into a unitary national framework would be called upon so-called Commerce Clause. By virtue of constitutional validation for the role of Congress under the interstate commerce requirements, the United States achieved a national integration with a free flow of commerce, in which the commerce clause functions as the legal ground to justify an exercise of congressional power, to say, with respect to the constitutional power of federal government. Europe is no exception. An integration of European Union (hereinafter referred to as EU) began with the abolition of tariffs among the countries of region and led to a high level of economic integration including the common trade policies and currencies as well as pursuit of political integration through the enactment of European Constitution. It generally is undisputable that it plays a crucial role for the economy to be systemized in terms of integration and discrimination. Therefore, if the WTO system harmonizes trade conflicts among nations and resolves them in accordance with the doctrines that can be firmly accepted by all, it is possible to achieve economic globalization of the world. An emerging unitary economic state cannot be said to be just an ideal. 
The Dispute Settlement Body (hereinafter referred to as DSB) within WTO is described in that the rule of law within the world trade regime, what is referred to as predictability and legal stability, will be an ultimate goal with the establishment of two tier judicial review, say, panels and appellate bodies. In this context, I would like to raise the following questions. First, what are the nature of rule of law and the role of judicial organs? Second and more specifically, what is the judicial role of WTO Panel or Appellate Body with respect to the rule of law, and is the current WTO framework functioning properly? Although this problem can be approached from various perspectives and requires a thorough discussion of the law and philosophy, this paper focuses on the problems of the WTO's appellate body, as well as some examples of comparative law and historical perspectives. For the convenience of understanding, it needs to be remarked that the WTO dispute settlement system differs from national judiciary organized under the framework of domestic enabling statute since it is instituted to serve the purpose of international organizations. Second, as predicated upon the tradition of long-standing international arbitration and its conventional influence, we will survey the arguably triptychs of elementary features, i.e. judicial review pursuant to the rule of law, independence of WTO judicial organs, and the supremacy of judiciary ${ }^{1}$. More specifically, the paper will deal with the importance of judge-made law through a recent development of WTO in terms of dispute resolution, debate on the extent of appellate body's judicial scope, the institutional nature of appellate body, its relationship with political institutions, and the judicial activism advocated by international pressure group or progressivists. Let's briefly review the proposition.

\section{Rule of Law and Justice System in the WTO Dispute Resolution}

The World Trade Organization is making efforts to secure the rule of law at the global level in international trade (Auby, 2003). If so, what is the rule of law, and what does it do for man and society? In principle, the rule of law is an ideology to prevent arbitrary domination of human beings and to realize the ideal of liberty and equal protection. Through the rule of law, human beings can secure predictability and legal stability in society and are protected from intervention against a legitimate trust. The rule of law has been aided by the development of modern civil society and liberal democracy. The main principles include the supremacy of constitution or parliamentary government, legitimacy of public power on executive and judiciary, as well as judicial review on administration. This kind of core principles enshrined with the rule of law has been transformed

${ }^{1}$ Kermit L. Hall, Unpublished lecture note. Utah State University: In the lecture, Professor Hall claims that the US Supreme Court has over 200 years of judicial review, judicial independence, and judicial sovereignty. This opposing claim may be a part of the value relating with the judicial system of United States but reflects closely the reality of WTO as affected from the US legal traditions or political economy. Not only is its impact considerable, but the recent development of Europe, as exemplified with the creation of EU, is comparable to the development of United States. 
from modern formal legalism to substantive rule of law. It is noteworthy that the rule of law plays as the axis of support for democracy by institutionalizing a domination of the majority through ensuring the democratic constitutionalism. By virtue of democratic constitutionalism, the government protects the legitimate rights and interests of minority from unjustifiable tyrannies (Kim, 2002). In order to realize the rule of law in international trade, it is necessary to accept the universal kind of global multilateralism and to reconsider existing gray-area measures through various agreements and judicial institutions in the end to liberalize trade. This means that the WTO guarantees predictability. In this direction, it had undergone a plethora of changes with a new deal, which sharply departed from the GATT, prior regime as vulnerable on political and diplomatic character.

In other words, the majority of countries in the world become members of WTO, resulting in the possibility of undemocratic containment by so-called bilateral practices and unilateral trade pressure. There has also been a revolutionary strengthening of the judicial review system to defend the principles of trade liberalization and fair competition. The dispute settlement understanding was adopted to systemize the dispute settlement procedures, to improve the efficiency of proceedings, and to establish the appellate body ensuring uniformity in the interpretation of WTO laws. The WTO also adopted a reverse consensus system to promote the rule of law ideal and enhanced judicialization of the dispute settlement mechanism. A unanimous mode of consensus practiced by GATT preferred a political and diplomatic governance over the dispute settlement procedure, in which it would be considered valid if the decisions of the Panel and Appellate Body were not rejected by the entire member states. Although there may be a controversy concerning the interpretation of Article 16 within the Understanding on Rules and Procedures Governing the Settlement of Disputes (hereinafter referred to as DSU), the decision of the panel and appellate body shall take effect immediately because at least the prevailing party would not veto and it is unimaginable for the whole of more than 140 members to deny it. In doing so, it introduced an unprecedented historical decision-making system that would enable the WTO to achieve an ideal universally embedded on the rule of law through panels and appellate bodies, while at the same time guaranteeing the political character of organization so that it should remain as an international organization with sovereign countries.

What features of the WTO framework are there in comparison with the rule of law in a sovereign state with respect to securing a formal and substantive legalism? First, it lacks the supreme law $^{2}$ to overwhelm the individual member ${ }^{2}$ In the case of claiming the supremacy of international law with respect to the relationship of hierarchy between domestic and international laws, such as Kelsen, there may exist the supreme law in the international society from an idealistic point of view. J. Peter Pham, The Perils of Consensus. Hans Kelsen and the Legal Philosophy of the United Nations, 14 Ind. Int'1 \& Comp. L. Rev. 553; The existence of supreme law is deemed as a last safeguard against the arbitrary political majority, which constitutes the basic belief of modern democracy and is a prerequisite for securing substantive rule of law. 
state, say, the kind of highest legislation to preempt the will or constitutions of member states. The WTO system consists with the multilateral treaties and is expected to practice as an international organization, while the treaties are created by the member states on equal shoulder and non-hierarchically. They function as the ultimate source of WTO law, in which the member states are a norm giver and norm receiver simultaneously. In other words, major agreements such as the agreement establishing the WTO, the agreements on trade in goods, and GATS (General Agreement on Trade in Services) or TRIPS (Trade-Related Aspects of Intellectual Property Rights) are merely treaties concluded between member states in terms of legal theory. Although the global states maintain differing attitudes regarding the validity of treaty and its status within the domestic legal system, they often deny the effect of treaty laws when conflict arises as contradictory to the Constitution. This means that that the WTO regime does not qualify to exercise a hierarchical power over the member states as dissimilar to the domestic legal system. In fact, it goes desultory in strict sense of legal process notwithstanding a retaliation or dismemberment, in case that the states do not voluntarily respect the treaties, lacking the kind of state power over person in the constitutional government. There may be no direct alternative if the major member states, in particular the United States or European Union, deny WTO agreements or ignore the decisions of the dispute settlement body on the basis of their highest law. ${ }^{3}$. The EU and European states are relatively good peers because their tradition comparatively tends to comply with the respect of international treaties and has a positive view of the WTO system. Otherwise, chances are not negligible to encounter, "if you are against my own national interests, I may derogate, based on our own highest law as well as the rule of law ideal envisaged with the launch of WTO".

Second, even under the formal rule of law, it is made distinct from the domestic rule of law owing to the difficulty and procrastination of legislation (Charnovitz, 2003). The WTO system is based on multilateral agreements, for instance, the establishment agreement or trade agreement on goods. In the case of indi-

\footnotetext{
${ }^{3}$ The existence of the supreme law and the supremacy of constitution are supported by the majority of constitutional scholars in Korea. In some cases, the decision of the WTO dispute settlement body may not be respected in Korea. Then WTO sanctions merely would be the approval of retaliatory measures and there is no mechanism to enforce the decision itself. Therefore, the supremacy of supranational bodies and UN Charter would not be realistically implemented in the secular terms, and thus it is generally recognized that there is a lack of supreme law or justice in the international community. For instance, the Byrd act was found to violate the WTO agreement, but the US Supreme Court upheld it was constitutional. In the case of EU, there is also a debate on the contradiction between the decisions of European Court of Justice and WTO dispute settlement body. A contradiction concerning ideals and reality for the supremacy of international law or the unitary international legal system does exist by any means. Jost Delbruck, Prospects for a World (Internal) Law. Legal Developments in a Changing International System, 9 Ind. J. Global Legal Stud. 401; Retaliation as regards trade issues can be a very effective measure to sanction, and phenomena, such as the trade war, that had been intense to bring a struggle over Calvo provisions in the past are unlikely to occur within modern international law regimes. However, as in the case of Korea, it has a limitation that the international law cannot directly nullify or revoke the domestic measures, and it can be distinguished from the domestic legal system on the supreme law, common ideals of politics and various values shared by the community.
} 
vidual member state, it is possible to make a necessary legislation promptly based on the principle of majority rule in the parliament and on the basis of common interests privileged with a cultural homogeneity. Not only because the possibly opposite side of understanding among negotiating parties gets it more complicated, but also because the amendment of treaty requires a multilayered process of law creation, the legislative response may be delayed. Of course, there is a certain level of common recognition among the countries in the international trade, and there are aspects that can be complemented by the negotiation technique developed for solving international problems. Therefore, an important axis inherent in the rule of law, which underwrites the priority of parliamentary legislation, can be an obstacle due to the difficulties or procrastination of revising the WTO Agreement. From the viewpoint concerning the rule of law, the current WTO system can be said to be relatively functional in terms of the judicial control or normative hierarchy to the end of ensuring a legitimacy for trade administration. However, from the viewpoint of lacking highest law as a lynchpin against being possibly desultory or in terms of often delayed legislation leading to the paralyzed formal rule of law, it is a system with disabilities. And these obstacles are inevitable due to inherent limitations within the WTO system as an international organization. Therefore, the rule of law under the WTO organization seems to be effective in the present stage by virtue of securing through a quasi-legislative role of judges concerning so-called judge-made law (Guerin, 2005; Beilin, 2003). The importance of judge-made law under the WTO governance ${ }^{4}$ increasingly became more urgent in the following points.

First, it is no exaggeration to state that the WTO system is being supported by the United States and European Union. In this reality, it can be effective to develop firmly an established rule that can be accepted by everyone in the international society through judge-made law by putting on specific cases of disputes rather than asserting a tremendous organizational reform. Organizational reform is at stake in the present stage. Instead, a rite law or paleo-verity on plain statement from the panel or appellate body may strand to enhance the rule of law and speak of the proper role of panels or judges. Second, the importance of judge-made law has traditionally played an important role in realizing an authentic service of the rule of law. It secures concrete validity and justice from the majority rule on the idea of parliamentarism and makes a great contribution to protecting the interests of just minorities. Institutionally, through the interpretation of constitutional law, for instance, judicial review or constitutionality review, the judiciary guarantees concrete and verifiable definition, protects system, guarantees principle of fair competition in society, and protects individual freedom. Currently, the WTO is operating on the basis of the dispute settlement understanding with respect to several substantive legal treaties and dispute resolution procedures, including the establishment agreement. Therefore, as a judge

${ }^{4}$ The statutory language is as follows: The Appellate Body may uphold, modify or reverse the legal findings and conclusions of the panel. DSU 17.13. 
in the case at bar, it is more likely to experience legislative vacuum or flaws than a domestic judge. For this reason, it is necessary to supplement the law by judge. Of course, the question of control as an arbitrator will remain. Third, in the realm of international trade and trade administration, two sources of norm conventionally have played as an important governing law, i.e. the practice of merchant society and precedents that had been developed since GATT. Over history, the British and American laws have been dominant in this area of law, and the tradition of diplomacy and treaty laws from the continent has been a major axis. Therefore, the composition of panel or appellate judiciary, judicial activities, philosophy, as well as legal theory and practice they espouse, are in fact the kind of critical intersection between the US and continental laws. In other words, in view of the overwhelming influence from US and EU, the legal system supported by two major powers will have a considerable influence. This view also pertains to the role of judicial decision makers in the WTO. Therefore, it is necessary to protect an ideology latent within the trade justice through the active role of WTO judicial organs although we face with the reality that it is bound to have limitations as an international organization. With respect to the principle of predictability, legal stability and certainty, there is a strong need for vigilant surveillance and control over arbitrariness or abusive practice utilizing the refined system of dispute settlement body.

\section{WTO Appellate Body as Marbury V. Madison's Reprint?}

The WTO Panel, as well as the Appellate Body, may function as a judicial organ in its original functioning, which may impose a challenge for the wholesale act. Although the appellate body has always emphasized its role and power as a typical judicial organ in resolving disputes, it has the character of being subordinate to the dispute settlement body or the ministerial council. The possibility of maintaining a judicial character similar to domestic courts requires a lot of review provided that the WTO panel or AB functions under the circumstances unlikened to the national judiciary. The issue of jurisdictional question for each sort of courts, as we see, is determined in most cases as based on the supreme law of nation and related statutes in an individual country. A little in variance, it is not only peculiar, but also profound in influence over global constitutional rule that it has been solved through the precedent of judiciary itself as we see in Marbury v. Madison ${ }^{5}$. The WTO Appellate Body also seems to be in a situation to benchmark the lesson of 18th US courts in 21st century. However, in the case of WTO disputes concerning international trade, the nature of agenda is not as simple as the judicial review on constitutionality, so that we see a peril if the WTO panel or appellate body may be disposed to the inconsistent practice should it rely on the precedents of appellate body without criticism, i.e. usurps to adjudicate non-justiciable case or too much actively exercises jurisdiction to obtain the common terms of justice.

5 U.S. (1 Cranch) 137 (1803). 
In other words, there are complications related to systemic flaws or advantages over the dispute settlement mechanism, such as uncertainty of jurisdictional scope, possibility of usurping the domestic jurisdiction as traversal, virtue of active judicial justice, and challenge to ensure the predictability of jurisdictions for appellate body. If the statutory ground for judicial authority of the WTO stems from $\mathrm{DSU}^{6}$, which, however, should not contravene the WTO establishing agreement, the agreement, in fact, shall have the same effect as a higher law against DSU. The DSU has only the principled provisions on the matters of authority for the panel or appellate body, so that it is often necessary to supplement by interpreting the relevant law. To simplify the problem, the WTO jurisdiction is amenable to a triad of classifications as, first, "what it can do", second, "what it should do", and third, what should not be done. With respect to the first category, DSU provides that the Appellate Body may uphold, modify or reverse the legal findings or conclusions of Panel $^{7}$ and, if the implementation of DSB's recommendations and rulings is not fully complied with, it can suggest ways in which the members concerned implement the recommendations ${ }^{8}$. The second category includes an obligation to keep under the recommendations and rules of DSU as well as surveil their implementation. The obligation to make up for the DSB working procedures in consultation with the chairman of DSB and the Secretary General also falls within the category as "what it should do". Other obligations pertaining to the second would underlie conducting appellate review for the panel's report including the findings and conclusions, suggesting ways to implement as a replacement, keeping confidential the documents submitted by the parties or third parties, as well as ensuring the opportunity to submit written and oral comments by the third party. Lastly and relating the third category of "what should not be done", it is necessary to forebear from ex-parte communication through the dispute settlement process and to avoid expanding or reducing the rights and duties under the covered agreement. DSU also forbids adjudging cases that are likely to arise in conflict of interest. Adjudication on issues raised lately on the $\mathrm{AB}$ proceedings is impermissible because it comes beyond the scope of jurisdictions and powers of the appellate body.

DSU is neither explicit to enumerate nor conceptually comprehensive to define the scope of powers vested within the appellate body. However, due to the inherent nature of jurisdictional question, it is necessary to exercise judicial power even if the statutory ground to confer the jurisdiction with DSU is lack-

\footnotetext{
${ }^{6} \mathrm{~A}$ former WTO Director-General characterized the WTO dispute settlement system as "the most active international adjudicative mechanism in the world today". Chad P. Bown of the Peterson Institute for International Economics and Petros Mavroidis remarked on the 20th anniversary of the dispute settlement system that the system is "going strong" and that "there is no sign of weakening". ${ }^{7}$ The statutory language is as follows: The Appellate Body may uphold, modify or reverse the legal findings and conclusions of the panel. DSU 17.13.

${ }^{8}$ DSU 19.1 consists of two statements. In the preceding sentence, it describes the recommendations of the post-hearing panel and the implementation measures of appellate body. In the latter sentence, together with the recommendations, it provides for specific measures to implement the findings or recommendations as follows, "In addition to its recommendations, the panel or the Applicant Body may suggest ways in which the Member concerned may implement the recommendations".
} 
ing. As exemplary, DSU guarantees the right of third party joinder, but comes to be silent in respect of its specific scope. For this reason, a plethora of precedents prove that it might contravene the requirements of adversary system by allowing the impermissibly wider chances of third party intervention (implying if DSU is often more involved than the parties).

Under the circumstances where the WTO has no choice but to ensure the interest of member states to fully claim their benefits and privileges because the organization is political or diplomatic in nature, the current system of third-party intervention seems hardly challengeable. However, with a grand scale reform, such as to adopt a reverse consensus system and rule of law framework, I think that a maintenance of wider third-party intervention likely comes incompatible with the founding cause of world trade organization in 1994. The appellate body may recourse to a number of substantive provisions in order to supplement the legislative deficiencies and to define the scope of jurisdiction and cure the ambiguities through precedent. The $\mathrm{AB}$ is prohibited from impermissible law-making because it should cohere with its character as an adjudicatory body. This forbearance also underlies the explicit provision of DSU that forbids to function as an undue legislative row. Therefore, it needs an enabling legal ground to create any jurisdictions on its own, as in the case of Marbury case.

DSU 3.2 stipulates that the WTO, in interpreting its agreements or memorandum, is required to comply with the customs of international public law and shall refer to the Vienna convention on the law of treaties ${ }^{9}$. Furthermore, the memorandum is understood to impose the duty of Vienna convention on the judicial organs of WTO. It also stresses the importance of speedy trial as a duty of $\mathrm{DSB}^{10}$. The behind policy to command with DSB in resolving a dispute much relies on the principle of good faith or bona fide efforts to peacefully resolve the dispute $^{11}$. It is, therefore, less on the kind of acidity inherent in the adversary system or judicial proceedings of national court. These provisions, in particular, DSU 3.2 and Vienna convention, afford the AB with the legal basis for a dynamic and progressive settlement without a prejudice to the rights and duties of member states under covered agreements.

If the selfdom of WTO appellate body on creation of jurisdictions is arbitrary and contentious, what will happen? As in Marbury for the United States Supreme Court, is it viewed to determinedly define the scope of jurisdiction with his own precedent as if susceptible of controversy? With respect to the rule of precedent and anti-majoritarian difficulty, can it be established and maintained through?

First, the possibility may well be destroyed from an institutional point of view (Howse, 2003). To put, the establishing treaty of WTO and relating agreements exclusively bestowed the power to finalize a treaty interpretation on political organs, such as ministerial conference or administrative bureau. Therefore, the ${ }^{9}$ See Article 31 of the Vienna Convention on the Law of Treaties.

${ }^{10}$ DSU 3.3

${ }^{11}$ DSU 3.10 . 
opinion of appellate body can be invalidated in the case if three fourth member states would agree as contrary to the precedent of jurisdictional determination ${ }^{12}$. Although the possibility is extremely slim that the legal interpretation of appellate body might be revoked, its authority is never final in terms of the logic and polemics within the WTO laws.

Second, there is a possibility of disagreement by the parties in dispute. The decision of panel or appellate body must be accepted without a condition unless a unanimous consent is accorded to the contrary. At this time, as a last resort, waivers may be sought in accordance with the establishing agreement of WTO conceptually higher to DSU in terms of legal effect. A quorum for exemption is three-quarters of the member states', but unanimity is needed according to the views of $\mathrm{AB}$ as mentioned above.

Third, if the appellate body's exercise of judgment on jurisdictional determination is inadequate, may disputing states bring an issue to the more general international tribunal or try to obtain the advisory opinion of International Court of Justice (hereinafter referred to as ICJ). Since the ICJ can give an advisory opinion exclusively to the specialized agencies of United Nations, there could be well-versed arguments to disagree. If the parties in dispute are contentious and the $\mathrm{AB}$ already made substantive decisions on the jurisdiction created on its own precedent, is it still possible to file a complaint with the ICJ claiming the illegal nature of jurisdictional self-creation. Separate perspective may stand. As opposed, the ICJ may not accept such a complaint because DSU provides for unconditional acceptance of the findings and recommendations made by $\mathrm{AB}$. On the other hand, the ICJ can have a room to exercise adjudicating on the complaint because the Statute of ICJ has provisions presumptive of the situation on this kind. For instance, the statute mandates its jurisdictional competence on the interpretation of treaty and the organizing agreement of international organization. More specifically, in the event of a complaint on this kind, the Court is required to notify the relevant international organization of the complaint and to send a copy of the document ${ }^{13}$. These provisions would be a circumstantial evidence to support the second view (Howse, 2003).

\section{The Appellate Body as a Judicial Organ: From the Arbitration Agency or International Trade Forum}

Unlike the GATT in the past, the World Trade Organization, as elaborated above, has largely embraced multilateralism and rule of law values for the realization of economic democracy. It is understood in this context that the appellate mechanism had been ordained in place as departs from the practice of GATT, but the nature of international arbitration still remains. Now that the WTO itself is not a legal entity on its own autonomy, but the kind of international organization subsidiary to the member states, it is likely that the attitude of appellate

${ }^{12}$ In a different viewpoint, the $\mathrm{AB}$ may, in fact, require a consensus or unanimous vote that follows the practice of GATT as a binding authority.

${ }^{13}$ See Article 34 (3), The Statute of the International Court of Justice. 
body will be an important variable in determining the degree of judicial characterization within the system. In other words, due to the limited nature of WTO dispute settlement mechanism, we see a weakness against our judicial thesis-latent in the nature of judicial advisory board to DSB, panel members leaning on arbitration or less on hard law concept, the lack of specific laws on dispute settlement procedures, as well as the flaws without systemic mechanism as differs from the domestic law enforcement. For example, in relation to the procedure of appeal, the issue arises how much the appellate body may be advised from outside sources about the fact or evidence and concerning the extent to which a relevant fact or information can be received outside of procedure ${ }^{14}$. In other words, the critical questions need to be answered whether it can be used as a source of facts, including a written submission on matters from persons other than the state parties in order for the discovery of substantive truth.

Only the state entity is exclusively qualified to become ae member of WTO besides a scanty exception, such as EU or some of separate customs territory like Hong Kong. On the other hand, the member states with a stake in the matter have the opportunity to participate in the proceedings as a third party and to argue by raising a defense or filing a claim. In such cases, individuals, public interest associations, non-governmental organizations, i.e. other than the parties to covered agreements, as not attached to the panel dossiers or written submissions of the parties, may state by independently filing a written submission. In the absence of a request from the appellate body, therefore, it is a question of whether the $\mathrm{AB}$ can accept them if it is stated through such independent written submissions on the matter, which likely would be an Amicus Curaie problem by the outsiders. In most cases of domestic civil proceedings, the principle of party autonomy advises that the court hears within the scope of assertion by the parties and may penalize the procedure if the court deviates from such scope. In some cases, the court may ex officio investigate or determine its authority and, in other cases or under the principle of public knowledge, it can be possible to acknowledge the fact without resorting to the court documents of parties (Beilin, 2003). As noted above, however, the legal nature of WTO dispute disposes that it has to do with the public law of international trade. In this respect, it is more prospective to further strengthen the power ex office or positive exercise of jurisdictions as relates to the professionalism of panel procedure or the process of appellate body. In the case of Turtles (WT/DS58AB/R, 1998), the written statement of non-governmental entity related to the investigation and examination of the panel and appellate body was a problem, and the panel concluded that DSU gave it the right to request a submission of relevant evidence ${ }^{15}$. The panel further opined that there is no right, therefore, for non-Members to submit non-requested ${ }^{14}$ In principle, the appellate body can only hear about legal issues raised within the panel proceedings as well as the panel's decision, but there is no clear yardstick to draw upon its jurisdiction in case where the appellate body applies the theory of "completing analysis".

${ }^{15} \mathrm{DSU} 13.1$ states that the panel may seek information or technical advice from an individual or organization which it deems appropriate; DSU 13.2 states that information may be obtained from relevant sources and experts of whom it can get the opinion. 
arguments or documents to non-Members in view of absent language concerning non-request. The appellate body has rejected the views of panel.

In its rulings, the appellate body states that the panel should not narrowly interpret the phrase "seek information" within the DSU, but rather interpret it more broadly in light of the basic purpose of evidence law or investigation procedure $^{16}$, which pursues a full disclosure of objective truth and facts as prescribed by the DSU. In addition, the principle of DSU requires a panel of faithful and objective assessment of the matter as described above and authorizes a power to create the specific rules of procedure ${ }^{17}$. The principle needs to be received broadly as to conceptualize the power to an objective assessment of the facts and to determine whether the act or inaction of parties violates the covered agreements. As a corollary, the panel's power to request disclosure of information is merely to prescribe some authority over the panel's factual hearing in special cases so that the panel may invoke a reference from outside sources as aground to determine facts, and if the panel had not done so, the appellate body could accept such reference material at the appellate stage. In particular, since DSU is neither completely systematic nor detailed unlike the domestic civil procedure law or evidence law, the panel needs to exercise its powers indispensably necessary to fulfill its obligations. In the case, the $A B$ accepts three non-governmental submissions attached to the panel dossiers of member parties and one reference materials independently submitted by that non-governmental organization.

Hereinafter, the $\mathrm{AB}$ opinion on the case will be briefly examined.

First, according to DSU, AB can only hear about the legal issues raised and adjudicated in the panel procedure as well as the panel's judgment ${ }^{18}$, and it does not appear that any clause in the working procedures or DSU expressly confers on the $\mathrm{AB}$ to request a disclosure of information. In spite of these problems, however, the appellate body reaffirmed its acceptance of reference materials in the Steel case (WT/DS138/AB/R, 2000). It illuminated that no provision of DSU or the code of practice on dispute settlement procedure stipulates the right to receive such reference materials. On the other hand, since it does not prohibit their acceptance, it could do so as necessary and in accordance with the provisions of authorizing an enactment of $\mathrm{AB}$ procedural rules ${ }^{19}$, to the extent that it does not expressly violate the DSU and WTO agreements. If it is necessary in all

${ }^{16}$ DSU 11 states that the role of the panel is to assist the dispute settlement body with regard to the DSU and the fulfillment of its obligations under the WTO Agreement. The dispute settlement body shall assist the parties to make appropriate recommendations and decisions. The panel shall consult regularly with the parties in dispute and shall provide them with an appropriate opportunity for mutually satisfactory resolution.

${ }^{17}$ DSU 12.1 stipulates that the Panel shall comply with the rules of working practice in Annex 3, unless otherwise decided after consultation with the parties to the dispute.

${ }^{18}$ The appeal is limited to the legal issues set forth in the panel report and the panel's legal interpretation of the issue. DSU 17.6.

${ }^{19}$ DSU 17.9 provides that the Appellate Body shall establish rules of working practice in consultation with the Chairman of the Dispute Settlement Body and the Secretary General and shall notify the Member States thereof 
cases to invoke an express ground in order to establish the scope of jurisdictional competence for $\mathrm{AB}$, we see it implausible with respect to practical considerations-a plethora of provisions as possibly supplemented with the interpretive discretion of $\mathrm{AB}$ judges as well as a probably impotent $\mathrm{AB}$ without such supplementary role of judges. In particular, the holdings of appellate body in Turtles were not based on the request for information disclosure under Article 13 of the DSU, but comprehensively considering the provisions stipulating the right of panel to enact such rules. Therefore, it is not appropriate to argue that the $A B$ cannot accept such an amicus submission unless it is explicitly granted the right to disclose information. It should also be noted that the $\mathrm{AB}$ is able to conduct a factual investigation in certain cases and it can help to form the basis of adjudication if the reference material contains factual statements as well as legal opinions. The $\mathrm{AB}$ opinion to define the status and authority on their own rationale is a last resort to selfdom. It can serve expanding its powers by using the right to enact rules on the panel or $\mathrm{AB}$ procedures in order to solve the problem in a number of cases where there is often insufficient evidence and flawed trial on the facts required in the panel procedure.

Second, the right to participate in the dispute settlement procedure involving parties or third parties ${ }^{20}$ through a submission of reference materials has not been generally recognized since 1947 GATT and until the WTO was established in 1994. In other words, the GATT or WTO is dealing with the issue of the formal nature of international trade, which is clearly limited by the provisions of WTO agreements ${ }^{21}$. However, the AB explicated that a language of WTO laws should be interpreted coherently of multifaceted intricacies within the express provisions and in light of the higher ideological command reflected on the WTO establishing agreement (hereinafter referred to as WTO Agreement). In other words, the member states should ensure that trade and trade policies are in place to improve the welfare of citizens, full employment, stable growth of real income, creation of effective demand, expansion of rights to trade within the system and comprehensively the benefits or interests of member states ${ }^{22}$. In this context, the critique outrightly can be skeptic as conservative to see that only member states are eligible to make a written submission within the procedure where environmental or health issues increasingly roar as a serious trade issue.

Third, the proactive stance of $\mathrm{AB}$ on the acceptance of reference materials can be criticized in terms of confidentiality or adversary system. However, it seems ${ }^{20}$ The parties to the dispute settlement procedure shall be limited to the member countries that participate as a party or a third party.

${ }^{21}$ In other words, the GATT/WTO elicits that it is not a legal system governing the relations between the 1947 GATT or the member states of WTO (1994 GATT) and the nationals of such member states or contracting states, saying "The GATT/ WTO did not create a new legal order that the parties involved in contracting parties or members and their nationals".

${ }^{22}$ The preamble of WTO Agreement is as follows, "Members recognize that their relations are in the field of trade and economic endeavor should be conducted with raising standards of living and ensuring full employment and a steadily growing volume of real income and effective demand and expanding the production of the rights of traders". 
well-meaning that discretionary accepting of pleading documents from a non-solicited third-party without the express legal ground does not contradict the principle of confidentiality among the $\mathrm{AB}$, party and third party whom DSU seeks to protect. In addition, we need to be aware that, in the case of litigation proceedings, the adversary system on party autonomy is not absolute and largely being revised even in the domestic legal system. It is also true that the ultimate objective of dispute settlement procedure is to satisfy the third parties having a conflict of interest with immediate parties in dispute as well as to perform the abstract control of WTO norms. Hence, it is not reasonable to emphasize the principle of adversary system without exception (Howse, 2003). In the course of dispute settlement, the parties acknowledge the $\mathrm{AB}$ power to discretion in selecting the parties and third parties. Furthermore, with respect to the procedural reality and goals-i.e. more efficient discovery of the substantive truth and objective normative control as well as general policy of non-disclosure against the party's interest, it is not unreasonable to support the practice of Amicus Curiae as legitimate in the $\mathrm{AB}$ procedure. This is particularly so in consideration of current panel and $\mathrm{AB}$ practice that legitimately deviates from or can render an opinion irrespective of the counts of action, issues and arguments raised by the parties.

Fourth, in practice, the $\mathrm{AB}$ judges may use a subordinate external method through reference materials to obtain legal advice or assistance. According to the DSU, AB judges are advised to be constantly concerned with the proceedings of WTO dispute settlement ${ }^{23}$. In addition, the ICJ statute deemed the legal opinion of renowned scholars as a source of international law so that it seems permissible for the $A B$ judges to seek legal advice or assistance. In fact, the precedent exists that the $A B$ had taken into account the reference studies of legal scholars for the resolution of cases. In such cases, it is not only the exception of adversary system, but also the parties are often unaware of such facts. In this context, the scope of acceptance for the references by outsiders needs to be expanded further, which can supplement judges' prejudice and ignorance with sufficient legal counsel (2003).

Fifth, the existing theories of comparative law require that the $\mathrm{AB}$ has discretion in accepting these reference materials. In the United States, the decision of the Supreme Court is legally binding the arbitration tribunals or state courts, which supports the practice that a legal counsel to the $\mathrm{AB}$ judge is highly essential. The International Court of Justice as well as various special international tribunals, e.g. the European Court of Justice, the European Court of Human Rights and the Inter-American Court of Human Rights accept these reference ${ }^{23}$ DSU 17.3 states, "the Appellate Body shall consist of persons recognized internationally as recognized experts in the substantive matters of law, international trade and agreements. The Appellate Body shall be independent from the Governments of the Member States and shall be constituted so as to represent the Member States in a satisfactory manner. The appellate judge shall always be available to work at all times upon request and shall always pay attention to and assist with the trends of the Parties on matters of dispute and the relevant measures of the WTO. And it cannot be involved in matters that are directly or indirectly likely to cause conflict of interest”. 
materials in order to provide legal counsel to the judges for resolving matters. In other words, the European Court of Human Rights recognizes the right to enact the rules of procedure in accordance with the European Convention on Human Rights $^{24}$, as similar to that of the $\mathrm{AB}$, and has already received such reference material prior to the legislation of the right to enact. Such powers have been customarily recognized and practiced by the inter-American court without an express legal ground, and the United States Supreme Court has the same experience $^{25}$. The right to receive such reference data has traditionally been welcomed in the Anglo-American tradition, where the principles regarding the autonomy of parties are more thorough than the laws of continental states (2003). As per the continental tradition, since the courts of continental law are more inclusive and inquisitive, it seems that the adoption of such a system was not necessary. Supporting the acceptance of these reference materials is thought to consist with the judicial nature of appellate body and denying them is contrary to the intention of establishing the WTO that purported to strengthen the judicial character of $\mathrm{AB}$ or rule of law basis resolution of trade disputes between countries. I argue that it is reasonable to see it positively. Otherwise, it is nothing but to unconsciously follow the arbitration legacy of tending to a strict focus on the parties. It is also difficult to see the $\mathrm{AB}$ as a professional throne or administrative potent even if it turns a little inquisitive, and the view is thought to cohere with the new enhanced judicial character of GATT system or the ideology of WTO as strengthening predictability and legal stability.

\section{Between the Appellate Body and Ministerial Hierarchy}

As stated above, the AB's authority to interpret covered agreements is not final. Under the WTO laws, the ministerial conference or general secretary exclusively exercises the power to approve treaty interpretation finally. Furthermore, in certain cases, the WTO rules and power of treaty interpretation may be excluded in principle under the agreements. The fact that the $A B$ does not have a final authority to interpret the agreements is important in establishing the common rule of law that the WTO pursues to achieve in the end, which requires a political sense of the judge. Let's take a look at two precedents. In the case of the Balance of Payments in India, the issue arose whether the government's measures to defend the balance of payments for the government of India violated by GATT provisions. As a threshold issue, the $\mathrm{AB}$ needed to decide whether the case belonged to any exclusive jurisdiction of the WTO committee on balance of payments (hereinafter referred to as CBP) or secretary general. The question of whether the trade organization's dispute settlement mechanism can coexist as a valid jurisdiction is emerging as an issue. The panel denied the claim of Indian

\footnotetext{
${ }^{24}$ Article 55 of the European Convention on Human Rights.

${ }^{25}$ In Webster, the court accepted the reference materials of government pointing out the unfairness of Wade. Webster v. Reproductive Health Services, 492 U.S. 490, 109 S.Ct. 3040, 106 L. Ed. 2d 410 (1989). In cases where the state power arises as an issue in the judicial process, the US government often submits an amicus brief to support its opinion.
} 
government under $1994 \mathrm{GATT}^{26}$, which claimed that the committee and the secretary-general had been given exclusive jurisdiction over violations. It concluded that WTO did not exclude the jurisdiction of dispute settlement body. In the appellate review on appeal from India, the AB elucidated that DSU should grant the dispute settlement body a general jurisdiction over the dispute concerning the breach of covered agreements ${ }^{27}$ and explicitly stated the absence of jurisdiction in Annex $2^{28}$. It furthered that the Annex 2 needed to read as limited. Therefore, the fact that domestic measures to defend the balance of payments deficits for developing countries are directly under the GATT clause that should be adjudicated by the member states (i.e. the balance of payments committee and the general secretary) does not compel a conclusion that it cannot be judged by the AB. As a counter, the government of India argued that the precedent of GATT was binding on the issue of jurisdiction, and that the member states possessed the exclusive right to decide on jurisdictional challenge. In response, the $\mathrm{AB}$ rejected that the GATT precedent relied on by India, as read in comport with the understanding on balance of payments, was reversed by the Uruguay Round and 1994 GATT. The government of India further stated that the understanding on the balance of payments would be absorbed into the dispute settlement procedure set forth in DSU only for the "application" of domestic measures to defend the balance of payments deficit. According to this statement, the issue of "substantive or abstract legality" concerning domestic measures still needs to be argued or decided by all member states that the political institutions of WTO should hear. However, the AB addressed an appellant's focus on "application" of the said clause in other context meaning that if the relevant domestic laws and ordinances are subject to the dispute settlement body's process, the compulsory clause can be recommended to abolish only if it violates the covered agreements. On the basis of compulsory and discretionary rules, the $\mathrm{AB}$ further elicited that statutory provisions amenable to implement on discretionary basis merely confirm the traditional GATT principle, in which they are subject to adjudication only if they are "effectively applied". On this account, the DSB can exercise its jurisdiction, whether it is "application" or "statutory provision". This attitude of $A B$, in fact, seems a rightful conclusion as a treaty interpreter and it is reasonable in terms of constructive interpretation of DSU, an important agreement of WTO, which clearly defines the meaning of provisions related to 1947 GATT.

Although the complainant's interpretation of appellate mechanism poses a complex problem, it should be seen as justifiable that the appellate body can ex-

\footnotetext{
${ }^{26}$ In terms of the 1994 GATT XVIII: B, the domestic balance of payments related to trade in goods shall be reviewed by the balance of payments committee and the general secretary.

${ }^{27} \mathrm{DSU}$ explains the procedures for the settlement of disputes shall be conducted in accordance with the WTO Agreement and DSU. It governs to settle disputes concerning the rights and obligations of parties that are alleged to conflict-individually or as multiple-with the covered agreements. DSU 1.1.

${ }^{28}$ Annex 2 enumerates nine cases of special dispute settlement procedures, including the special dispute resolution clause within eight agreements or plurality agreements, for instance, the Sanitary and Phytosanitary Measures 11.2 and the Agreement on Textile and Clothing 2.14 and 2.21.
} 
ercise judicial power over the "substantive legitimacy" of the India's balance of payments policy as well as "application". The rationale is on several grounds. First, the $\mathrm{AB}$ has a primary responsibility to clarify the relationship between DSU-that generally sets out the dispute settlement procedure for covered agreements-and the special procedure for resolving the dispute of covered agreements. The system stipulated that the main purpose was to give legal stability and predictability to multilateral trading system ${ }^{29}$, and although the phrase "application" was used in legal terms, the argument of India was not plausible to find that it consisted with the laws of DSU to override the GATT Principles. This was because, according to the opinion of $\mathrm{AB}$, the argument is simply grounded on reading of annotation, but asserts to contradict a more important main text of provision. Therefore, the $\mathrm{AB}$ found it least persuasive or hard to sustain to view that provisions spelled out for general jurisdictions would be excluded and not apply to the domestic measures infringing with the benefit and interest of member states. It unduly restrains the jurisdiction of DSU and should be unfair in terms of equity among the states.

The government of India also argued that it was unfair to exercise the jurisdiction given a constructive and balanced understanding over multiple source of WTO laws, which was rejected by the AB. There is a criticism for the decision of rejection (Roessler, 2000). To put, although the exercise of judicial power by $A B$ does not in any way exclude the authority of WTO committee to adjudicate on the balance of payments issues, it can actually nullify it. In other words, the decision of CBP is ineffective since it is, in nature, requiring the unanimity of member states while the appeal mechanism by a small number of judges is more effective, so that the CBP can be rendered impotent as a matter of WTO practice. A situation, in which the $\mathrm{AB}$ decision actually would be compatible with the intent of one prevailing state and same of value with the consensus of CBP, can occur. This is a situation where the WTO stands on international agreement, and therefore it is not desirable from a point of balanced perspective. There also is a concern that the GATT regime may reproduce the problem of conflict between political and judicial. The scholars critical of $\mathrm{AB}$ findings on this regard argue that it is necessary to defend a new WTO system, which was envisaged as congruent with the establishment of rule of law and state sovereignty, such as the introduction of the reverse consensus system while respecting the decisions of political institutions. This view emphasizes that the balance of payments problem is traditionally a matter of political character, not susceptible of the dispute settlement body whose mission is to interpret the covered agreements. However, the counterargument to these critical views may be built in that it is, in fact, nothing but a principle to be interpreted in accordance with the Vienna convention on the law of treaties requiring the resolution of dispute settlement bodies to defer to the decision of political authorities ${ }^{30}$. The scholars to support AB find${ }^{29}$ The text of DSU 3.2 is as follows: "The dispute settlement system of the WTO is a central element in providing security and predictability to the multilateral trading system ..."

${ }^{30}$ Article 31 of the Vienna Convention on the Law of Treaties. 
ings, therefore, loomed to posit that interpretation of treaty clauses generally fall within the adjudicatory body of organizations as referred to the practice of international customary law. They safely refute the criticism of $\mathrm{AB}$ findings on the ground that treaty interpretation is an original role of the dispute settlement body. In their viewpoint, because a narrow reading resulted in the limited role of dispute settlement mechanism is unacceptable in view of the general jurisdiction provision under the DSU and active judicial control over trade. On this ground, $A B$ 's finding is deemed precisely fine that it was a legitimate forum to hear a case through the assistance of many UN agencies including the International Monetary Fund (IMF).

Another question is whether the $\mathrm{AB}$, an adjudicatory agency of WTO, can determine for itself the existence of legal jurisdiction over the balance of payments issue. The state parties (the United States and India) did not raise a preliminary objection "no competent jurisdiction" on the balance of payments, which would greatly enhance the role of DSB as catalyzed with the reverse consensus system proving that the dispute settlement mechanism would develop into a role similar to that of other international organizations. In addition, the finding would convince that the dispute settlement mechanism can be regarded as strengthening a breakthrough between the old GATT and new WTO system. In particular, it is significant that the United States, a leading WTO member, had not raised such a plea.

Another example of the inter-institutional equilibrium dilemma is the Turkish Textiles case (WT/DS34/AB/R, 1999), in which the Turkish government's import restrictions on joining the EU's customs union became a subject of adjudication $^{31}$. The GATT permits the creation of customs unions or free trade zones under certain conditions, one of which requires not to violate the obligations of covered agreements as provided for in other GATT provisions. This requirement needs to be respected when establishing the customs union or free trade zone. To be precise, the obligation to abide by non-discriminatory principle as stipulated by the $\mathrm{GATT}^{32}$ is urgently important to obey even after creating the customs union. This means that exemption from the duties of member in relation to the creation of customs union shall only be made of GATT obligations contrary to the nature of customs union. Thus, obligations as treaty countries in general are not exempted. Similar to the previous case, the Turkish Textiles also stipulated that the GATT or member states should review the suggestion of customs union and recommend on whether it is contrary to the requirements of GATT. Even if it does not meet the requirements strictly, the establishment of customs union or free trade zone can be legitimated with the consent of three-fourths vote of member states ${ }^{33}$ and in accordance with the basic of Uruguay Round agreement $^{34}$.

${ }^{31}$ See GATT XXIV

${ }^{32}$ GATT I.

${ }^{33}$ GATT XXIV: 7.

${ }^{34}$ According to the Understanding on Article XXIV agreed in the Uruguay Round, at least the requirements of paragraphs $5,6,7$, and 8 must be met. 
In any case, with respect to the creation of customs union or free trade zone, WTO laws give the right of review to the council on trade of goods ${ }^{35}$ and concurrently recognize the jurisdiction of dispute settlement body. In this respect, the panel avoided judging the issue of jurisdiction for the dispute settlement body, arguing that it had nothing to do with the creation of customs union and, consequently, did not need to make judgments about the existence of jurisdiction as a matter of judicial economy. In appellate review, the $\mathrm{AB}$ reiterated as dictum that the jurisdictional disagreement should be resolved by referring to the above precedent on the balance of payments case. And it is doubted to conclude, according to the opinion of $\mathrm{AB}$, that it is not related with the creation of customs union without reviewing whether the import restriction in question meets the requirements for establishing it. In considering the appropriateness of decision, the following three situations may be assumed; 1) if the creation of customs union or free trade zone is granted by the members 2) if it is denied 3) if the member states still did not express its views through the political institutions, and so on. In former two cases, it is not possible for the $A B$ to exercise its competence of jurisdiction, which should be impermissible in light of the balance of instruments or practices of the parties to the Vienna convention on the law of treaty. Then the final outcome should be accorded to the decision of political authorities and the $\mathrm{AB}$ needs to defer. However, if the appellate body is not able to exercise judicial power in cases where there is no decision yet by the political organ, the state party that had violated the GATT or other covered agreements may continue to use such legal void to maintain its violation. The unreasonable inconvenience arises in which the parties damaged with the benefit and interest under covered agreements cannot take any measures to defend their rights. On the contrary, the parties that the domestic measures are is in conformity with the requirements and the creation of customs union is urgent to their benefit and interest can be injured because of the legal void.

In this situation, we need to be aware that, even if the appellate body exercises judicial authority, it does not mean to exclude the right of review by political institutions. Then, the $\mathrm{AB}$ findings and recommendations may result in conflict with the decisions of political institutions in the future. Assume if the domestic measures in question violate the covered agreements of GATT but is decided to be legal under the special provisions on customs union while the political institutions decide in the future not to do so. In this hypothetical case, it would be certain that the complaint state shall ask $A B$ to retry. On the contrary, if the $A B$ determines inconsistency with the customs union requirement and the political body has made a decision as opposite, the defeated party shall restore domestic action already found to breach the covered agreements and the prevailing party which is dissatisfied with the decision of political organ shall demand a reconsideration. In the review process on reconsideration, the $A B$, arguably a dispute resolution body in judicial character, seemingly would be more appropriate to ${ }^{35}$ GATT XXII, XXIII. 
uphold the decision of political organ, and therefore the creation of customs union shall be considered possible and as legitimate finally. These two hypothetical situations show that the relationship between the $\mathrm{AB}$ and political institutions is complex. As noted below, the $\mathrm{AB}$ is systematically different from domestic courts. Because of its nature supported by the international covenant among sovereign states, it is influenced by the complex variables in defining the scope of its own authority. The potential problems also are not least, such as efficiency of the remedy, possibility of faithfully implementing the recommendation, check and balance among the intramural organs, as well as the nature of issue or possible conflict with political institutions. However, considering the reality of new WTO system, the possibility that the exercise of active jurisdiction over dispute settlement mechanisms will lead to opposition by political institutions seems to be unlikely. This leads to justify our suggestion that it is necessary to exercise active judicial power in view of strengthening the rule of law.

\section{Judicial Activism of WTO Appellate Body}

It is a well-known fact that there has been an ideological conflict between judicial activism and judicial passivism concerning the rule of law or the role of judiciary. As we know, the role of judiciary as an agent of divine monarchy and one bureau for the absolute king has been an axis supporting the emergence of democracy based on the electoral system and separation of powers advanced by John Locke and Montesquieu. The independence war and French revolution are regarded as historical events that have made a great contribution to the development of democracy. The judiciary has played a major role in defending freedom and justice and maintaining the unity of nation, as US history proves. It is no exaggeration to say that the judiciary has been a key actor with the power to judicially control the legislative and executive branches. The judicial branch had also stood at the center of government that formulated crucial value of nation through the interpretation of federal constitution. However, it has always been questioned how the judiciary of most countries, as well as the United States, will play its part within the conflict of politics and law.

A chaos of American society surrounding the servitude system, confrontation between president Roosevelt and supreme court, as well as social reform legislation in the early 20th century all would be illustrated as a state of repression for social progress or conservatism among the struggle involving politics and law (Keller, 1990). Regarding the role of judiciary, well-meaning scholars and pundits emphasize judicial activism. International traders and interest groups are also demanding more active judicial intervention of the appellate body. Along the discourse on judicial activism and passivism, we are able to find the underlying concern of values neutral as they are. In this aspect, judicial activism for conservative society is not unreasonable in logic and theory. In most cases, however, judicial activism usually calls upon a combination of social ideology and progress of community. The judicial power is a state function with a unique 
character among the three branches of government, which basically triggers the relief of individual rights on case or controversies. If the legislative power is an abstract act of power, then the judicial power coheres with its passive nature to hear cases or controversies initiated by disputed parties. Therefore, it can be closer to individual people than other two brother branches, and social progress can be achieved through adjudicating on historical or socially significant events on clamor. On the other hand, judicial power delivers a specific justice of abstract value enacted by legislature as similar to the executive power, but its adjudication is ultimate in accordance with the principle of finality for judicial authority. In this regard, the judiciary could be easy to have a tendency to be conservative, and the principle of coherence and precedent would be a dominant value of practice (Guerin, 2005).

Judicial activism must be understood in these limitations so that it is difficult to accept judicial activism as an assertion in the sense that can easily be achieved as proposed by lay writers or general commentators. Our reality is that it only can be approached in any most plausible or effective way among the conflict of values and calibrations, given enactment and court precedents. It has to do with the ideology concerning the rule of law in pursuit of legal stability and predictability. Every citizen has the right to freedom and justice, and he may doubt, "the citizens who are involved in the case and adjudged, may deprave why it was so in the past, but why it is different today". The role of court is nothing but to respond with this kind of inconsistency and social injustice that has an obligation to explain it properly. In the condition of society as extreme or unsustainable where legal stability and predictability are not guaranteed, incapacity and private retaliation would be prevalent and the actor could not make any rational decision. The notion of judicial activism would be historically valid if understood with respect to the judicial system of United States. In fact, the judiciary actively exercised its power or constitutional competence in the course of developing the unity of nation under federalism on the cause of judicial activism, thus subjugating the state government while forming and developing the national values. In the same way, it is in common with the political value of social progress and transformation to humanity or emancipation.

If we talk about judicial activism in the context of international law, we need to begin with the famous Lotus case. In other words, the ICJ in that case declared the important principle influential over subsequent case laws that the state shall exercise its sovereignty freely and without abridgement unless a specific obligation is imposed on it (P.C.I.J Reports, 1927). In the absence of a specific obligation, the ruling implied that the international adjudicators could check the nation as a subject of international law by only means of positive interpretation to impose certain duties. At this time, there could be a room for conflict between the value that the state should defend and the judicial value of judges serving international organizations. For instance, how to resolve a dispute filed with the panel or $A B$, in fact, would be challenging where there are complex conflicts 
among the authority of state actors involved with the newly emerging health and environmental laws and trade controversies. Is it reasonable for the $A B$ judges to correct domestic health policies? Judicial activists will, of course, emphasize the active role of judges for the advancement of society. At this time, however, the judges, as mentioned above, have an obligation to exercise their jurisdictional competence while accepting the complexity of values underlying the rule of law ideal. It is in conformity with the revolutionary ideology to transform a long-standing trade organization in order to idealize to secure the rule of law within the real trade arena. If it is influenced by political arguments and restrained to its passive tradition, the ideology of rule of law in the international trade administration would come far vitiated to arouse a public dissent or criticism. Since the subject of WTO covers the economy and trade, the corresponding discourse on rule of law raises an international focus of attention as dissimilar with the sensitive areas of international politics, human rights or criminal law. This means that, pertaining to the trade jurisdiction, we can have an ample opportunity to experiment the rule of law framework in the WTO and, under the consensus of global commons, we even may look forward to the prospect of political unification of the international society in the future.

Then we can see that there are several conditions predicated on judicial activism with respect to the rule of law.

First, judicial activism is to expect the active and political role of judicial authorities, and on the other hand, there is a restriction that it cannot go beyond the interpretation and verification of recognized legal norms due to the inherent limitations of judicial power (Kim, 2014). This means that the state actors subject to jurisdiction should be provided with legal stability and predictability and the panel or $\mathrm{AB}$ should provide certain judicial standards in accordance with the principle of stare decisis (Guerin, 2005). History shows that the precedents accumulated through adjudication on cases or controversies play a major role in rationalizing society, and the kind of political sense like a Machiavelli could be desired qualities of judges in a usually complex situation. The importance of precedent is common to both legal traditions across two continents. The final authority to interpret constitution in relation to judicial activism has an important meaning in the modern government system. The judge can identify and educate more basic national values through the constitutional interpretation, so that the area in which judicial activism functions can be broadened. Judge-made law is made up of these complex circumstances, and especially in the American constitutionalism, the trust and respect of judiciary is relatively strong because of the legal culture formed by the principle of precedent (2005).

Second, the above conditions are given to the ordinary domestic judicial system. In terms of international judiciary, judicial activism is given more complex circumstances. Examples of WTO dispute settlement bodies are: 1) the legal system constituted by WTO Agreement and many related agreements is essentially an international treaty; 2) the supreme body of WTO shall be a ministerial con- 
ference composed of ministers from the respective countries, and the decisions of panel or appellate body formally take a form of recommendation-not judgment or order, hence, nuanced neither coerced nor forcefully enforced-for the implementation of certain matters; 3 ) it shall have effect when it is finally adopted by the DSB, i.e. organization of political nature. In other words, the interbranch subtlety and balance is not secured according to the principle of separation of powers as distinct from domestic ruling structure, in which the panel or appellate body merely assists with the character of political supremacy as a judicial counsel. It is in contrast that most enforcement agencies of domestic law strictly preserve the character of constitutional power, such as neither being able to give an advisory opinion nor exercising jurisdiction when the effective remedy of an individual's rights is impossible-as seen in moot case principle, for instance.

Third, the WTO Agreement is neither detailed nor sufficiently intricate as distinct from national laws that it is often difficult to find a clear legal ground to discern what the judge can and cannot do. For various reasons, such as legislative deficiency, the WTO can be regarded as an interdisciplinary room between the civil and common law traditions or the nurturing organization to subsidize major WTO members including the United States and European Union. In this case, the panel or AB judges must be Machiavellian in order to secure the rule of law in the trade arena, which are circumstances far worse than the domestic judiciary. If the United States and European Union contend with excessive judicial activism by proposing national interests, many difficulties can arise even if they forbear from going to ground zero by renouncing a foundational agreement. Although WTO agreements are relatively legal and has a scope of leeway amenable to legislative supplementation by the judges, there may be a problem of self-ethics caused by less on law and more on arbitration or ignorance of law on judicial populism. Furthermore, even if adjudication is reasonable and shrewd to wisely resolve the trade controversies, it remains possible that the superpowers are implicit to pressure. With the establishment of GATT in 1947, the international administration on trade issues had begun their business. Even under the old GATT, there had been dispute settlement procedures such as panels, but the creation of WTO in 1995 is said to revolutionize them in the direction of strengthening the judicial character. Similar to the new constitutional court of South Korea and Supreme Court of United States, there have been compiled of many precedents under the WTO system since 1995, but this is never comparable to the evolution and accumulation of precedents within the advanced empires of law, for example, the United States. In sum, WTO judges are fated to face the challenge of finding a role as a wise ruler in trade amongst the possibly legal, cultural or diplomatic assault of major members, i.e. United States or EU, as well as with the surrounding political pressure. As regards judicial activism under the WTO, the judiciary sets as a starting point the principles of international law that, if its obligations under international law are not clear, it should not impose obligations restricting national sovereignty and respect the principle of non-intervention in the internal affairs. In view of judicial activism, it is per se 
required that judges need to go beyond a simple fill-in-the-blank dimension to determine the value and increase a protection through judge-made law (Beilin, 2003). Even if he or she has a leeway since no obligation is expressly specified in a given agreement, it is more difficult to draw the obligation and to limit national sovereignty or the act of government than domestic judicial authorities because the international organization has a unique political personality. For the sake of argument, I like to highlight that there is a similar aspect to the role of federal courts under federalism in the legal history. For the past, we know that the legal form of nation once had been similar to that of EU as weak or vulnerable, in which the Supreme Court is comparable to the European Court of Justice in terms of its role for integration and common values. Under the circumstances, judicial activism of the Supreme Court was required to play a central role. The lesson of history convinces that it is a conundrum as a matter of practice or concerning the extent of judicial activism, whether the $\mathrm{AB}$ needs to intervene with the matters that the interest of domestic governments is sharply relating to trade principles, for instance, health and environmental policies.

\section{Conclusion}

While hoping to expect more research in the future, I have examined a part of problems entangled with judicial activism of the WTO dispute settlement body as aided by the lessons of history or comparative law as well as precedents. The WTO is ambitiously moving forward to the rule of law principle within the international trade arena as verified through new DSU and its decadal practice. However, the given circumstances are throwing a very long-lasting task. Unlike the old GATT system, it should be able to guarantee legal stability and predictability for the relevant actors in order to have a more systematic and effective judicial control. Their responsibility is to play an active role for the evolution and progress of international society. We believe that there should be constant efforts to establish a reliable judicial system to overcome the remains of conventional arbitration procedure. Unless a regime of case law is intricated in which lawmakers of the civil or common law traditions can be persuaded, it is unlikely or hard to refute the malaise or private retaliation of superpowers and other members. A solution cannot be achieved by legislative efforts alone. Furthermore, under the WTO governance, it is more cumbersome to rely on legislative solutions than in the domestic case. Therefore, I believe that it seems to be the most efficient way to have an enriched, well-refined and intricate system of precedents comparable to the US and concerning the rule of stare decisis. We see it regrettable that it is confined to the economic domain; however, Machiavelli $s$ wisdom and Kantian idealism hopefully can be expected of WTO panels and AB judges.

\section{Acknowledgements}

The author thanks the faculty of Chosun Law, who supported with the advice and suggestion in preparing this manuscript. The financial support of Chosun 
University is also acknowledged.

\section{Conflicts of Interest}

The author declares no conflicts of interest regarding the publication of this paper.

\section{References}

Article 31 of the Vienna Convention on the Law of Treaties.

Article 34 (3), The Statute of the International Court of Justice.

Article 55 of the European Convention on Human Rights.

Auby, J. B. (2003). La Globalization, Le Droitet L'Etat (pp. 154-160). Paris: Montchrestien.

Beilin, L. W. (2003). In Defense of Wisconsin Judicial Notice Rule. Wisconsin Law Review, 499, 508.

Bethlehem, D. L., McRae, D., Neufeld, R., \& Van Damme, I. (2009). The Oxford Handbook of International Trade Law. Oxford: Oxford University Press. https://doi.org/10.1093/oxfordhb/9780199231928.001.0001

Carr, I., \& Stone, P. (2017). International Trade Law. London: Routledge. https://doi.org/10.4324/9781315543970

Charnovitz, S. (2003). The Emergence of Democratic Participation in Global Governance (Paris, 1919). Indiana Journal of Global Legal Studies, 10, 45-77. https://doi.org/10.2979/gls.2003.10.1.45

Dam, K. W. (1970). The GATT: Law and International Economic Organization. Chicago, IL \& London: The University of Chicago Press.

Delbruck, J. (2001). Prospects for a World (Internal) Law: Legal Developments in a Changing International System. Indiana Journal of Global Legal Studies, 9, 401-431.

Guerin, D. M. (2005). Why an Independent Judiciary. Wisconsin Lawyer, Oct. 2005.

Hall, K. L. Unpublished Lecture Note. Logan, UT: Utah State University.

Howse, R. (2003). The Most Dangerous Branch? WTO Appellate Body, Jurisprudence on the Nature and Limits of the Judicial Power. In T. Cottier et al. (Eds.), The Role of the Judge in the International Trade Regulation-Experience and Lessons for the WTO: The World Trade Forum (Vol. 4, pp. 15-16). Ann Arbor, MI: The University of Michigan Press.

Keller, M. (1990). Regulating a New Economy: Public Policy and Economic Change in America, 1900-1933. Boston, MA: Harvard University Press.

Kim, K. (2002). Constitutional Lecture (pp. 27-51). Seoul: Park Young Sa.

Kim, K. (2014). The Relationship between the Law and Public Policy: Is It a Chi-Square or Normative Shape for the Policy Makers? Social Sciences, 3, 137-143.

https://ssrn.com/abstract=2577832

https://doi.org/10.11648/j.ss.20140304.15

Lee, C. S. (1999a). International Trade Law (pp. 111-118). Seoul: Park Young Sa.

Lee, Y. D. (1999b). Studies on Domestic Regulation and International Trade. Human Rights and Justice, No. 208.

Pham, J. P. (2003). The Perils of Consensus: Hans Kelsen and the Legal Philosophy of the United Nations. Indiana International \& Comparative Law Review, 14, 553-584. 
https://doi.org/10.18060/17820

Roessler (2000). The Institutional Balance between the Judicial and Political Organs of the WTO. Conference on Efficiency, Equity and Legitimacy: The Multilateral Trading System at the Millennium, 1 June 2000.

Seo, J. D. (2001). International Trade Law (pp. 107-142). Seoul: Sam Young Sa.

The Sanitary and Phytosanitary Measures 11.2 and the Agreement on Textile and Clothing 2.14 and 2.21 .

WT/DS138/AB/R (2000). United States-Imposition of Countervailing Duties on Certain Hot Rolled Lead and Bismuch Carbon Steel Products Originating in the United Kingdom.

WT/DS34/AB/R (1999). Turkey-Restrictions on Imports of Textile and Clothing Products.

WT/DS58AB/R (1998). United States-Import Prohibition of Certain Shrimp and Shrimp Products. 


\section{Appendix}

DSU-Understanding on rules and procedures governing the settlement of disputes, Annex 2 of the WTO Agreement, 1.1.

DSU-Understanding on rules and procedures governing the settlement of disputes, Annex 2 of the WTO Agreement, 3.2.

DSU-Understanding on rules and procedures governing the settlement of disputes, Annex 2 of the WTO Agreement, 3.3.

DSU-Understanding on rules and procedures governing the settlement of disputes, Annex 2 of the WTO Agreement, 3.10.

DSU-Understanding on rules and procedures governing the settlement of disputes, Annex 2 of the WTO Agreement, 11.

DSU-Understanding on rules and procedures governing the settlement of disputes, Annex 2 of the WTO Agreement, 12.1.

DSU-Understanding on rules and procedures governing the settlement of disputes, Annex 2 of the WTO Agreement, 13.1.

DSU-Understanding on rules and procedures governing the settlement of disputes, Annex 2 of the WTO Agreement, 13.2.

DSU-Understanding on rules and procedures governing the settlement of disputes, Annex 2 of the WTO Agreement, 17.3.

DSU-Understanding on rules and procedures governing the settlement of disputes, Annex 2 of the WTO Agreement, 17.6.

DSU-Understanding on rules and procedures governing the settlement of disputes, Annex 2 of the WTO Agreement,17.9.

DSU-Understanding on rules and procedures governing the settlement of disputes, Annex 2 of the WTO Agreement,17.13.

France v. Turkey, P.C.I.J. Reports, Series A. No. 10 (1927).

GATT 1947-The General Agreement on Tariffs and Trade, XXIV.

GATT 1947-The General Agreement on Tariffs and Trade, I.

GATT 1947-The General Agreement on Tariffs and Trade, XXIV: 7.

GATT 1947-The General Agreement on Tariffs and Trade, XXII.

GATT 1947-The General Agreement on Tariffs and Trade, XXIII.

GATT 1947-The General Agreement on Tariffs and Trade, XVIII: B.

Marbury v. Madison, 5 U.S. (1 Cranch) 137 (1803).

The Preamble of WTO Agreement.

Webster v. Reproductive Health Services, 492 U.S. 490, 109 S.Ct. 3040, 106 L. Ed. 2d 410 (1989). 